\title{
Safe Embrace: technological innovation for elderly safety in the use of toilets
}

\author{
Abraço Seguro: inovação tecnológica para segurança de idosos no uso do sanitário \\ Abrazo Seguro: innovación tecnológica para seguridad de ancianos en el uso del baño
}

\author{
Luciana Mitsue Sakano Niwa', Nanci Martins Ferreira Radovich', \\ Eliseth Ribeiro Leão", Suely Itsuko Ciosak' \\ ' Universidade de São Paulo, Escola de Enfermagem. São Paulo, Brazil. \\ "Hospital Israelita Albert Einstein, Instituto de Ensino e Pesquisa. São Paulo-SP, Brazil.
}

\section{How to cite this article:}

Sakano LMN, Radovich NMF, Ciosak SI. Safe Embrace: technological innovation for elderly safety in the use of toilets. Rev Bras Enferm [Internet]. 2018;71(Suppl 6):2833-6. [Thematic Issue: Good practices in the care process as the centrality of the Nursing] DOI: http://dx.doi.org/10.1590/0034-7167-2017-0751

Submission: 12-17-2017 Approval: 03-28-2018

\begin{abstract}
Objective: to describe the development of a device to prevent falling for seniors when using the toilet. Method: we sought in literature and in the hospital market for a device to prevent falling, without success. Geriatric nurses, in partnership with the hospital engineering team, elaborated a prototype and, after several analysis, looked for a partner for its production. Results: the device, named "Safe Embrace", installed and tested in an apartment of the Geriatric ward, was positively evaluated by the health team, patients and caregivers. Conclusion: for the benefit obtained and considering the safety and privacy during use, Safe Embrace was patented so that other institutions could use it.
\end{abstract}

Descriptors: Accidental Falls; Patient Safety; Nursing; Frail Elderly; Equipment Design.

\section{RESUMO}

Objetivo: descrever a elaboração do dispositivo de prevenção de quedas para idosos durante o uso do sanitário. Método: buscou-se na literatura e mercado da área hospitalar um dispositivo para prevenir queda, sem sucesso. Enfermeiras da geriatria, em parceria com a equipe de engenharia do hospital, elaboraram um protótipo e, após várias análises, procuraram um parceiro para sua produção. Resultados: o dispositivo, nominado "Abraço Seguro", instalado em um apartamento da geriatria para teste, foi avaliado positivamente pela equipe de saúde, pacientes e cuidadores. Conclusão: pelo benefício obtido e considerando a segurança e privacidade durante o uso, o Abraço Seguro foi patenteado para que outras instituições desfrutassem dele.

Descritores: Acidentes por Quedas; Segurança do Paciente; Enfermagem; Idoso Fragilizado; Desenho de Equipamento.

\section{RESUMEN}

Objetivo: describir la elaboración del dispositivo de prevención de caídas para ancianos durante el uso del baño. Método: se buscó en la literatura y mercado del área hospitalaria un dispositivo para prevenir caída, sin éxito. Las enfermeras de la geriatría, en asociación con el equipo de ingeniería del hospital, elaboraron un prototipo y, tras varios análisis, buscaron un socio para su producción. Resultados: el dispositivo, denominado "Abrazo Seguro", instalado en un apartamento de la geriatría para la prueba, fue evaluado positivamente por el equipo de salud, pacientes y cuidadores. Conclusión: por el beneficio obtenido, y considerando la seguridad y privacidad durante el uso, el Abrazo Seguro fue patentado para que otras instituciones lo disfruten. Descriptores: Accidentes por Caídas; Seguridad del Paciente; Enfermería; Anciano Frágil; Diseño de Equipo. 


\section{INTRODUCTION}

In Brazil, data from the 2010 Census showed that the population aged 60 years or more represents about $10.9 \%$ of the current 190,732,694 inhabitants ${ }^{(1)}$. For this population, falling is a serious problem, being the primary etiology of accidental death in people over 65 years. According to data from the Mortality Information System of the Ministry of Health ${ }^{(2)}$, between the years 2010 and 2015, about 72,640 people died from a fall, of which $69 \%$ were individuals aged 60 years or more.

By definition, falling is the body's unintentional dislocation to a level below the initial position, which cannot be corrected in due time, determined by multifactorial circumstances that compromise stability ${ }^{(3)}$. Falling stems from a total loss of postural balance and may be related to sudden failure of neural and osteoarticular mechanisms involved in maintaining posture ${ }^{(3-4)}$.

Falls generate decline in the elderly population's health due to the restrictions they cause to daily life activities and to the fear of a new fall. Consequently, they also prolong hospitalization time, increase the treatment cost and can lead to serious injuries with increased comorbidity, dependency, impairment of recovery and patient's death, in addition to the anxiety of the care staff, loss of trust in the institution and possible occurrence of legal proceeding $\mathrm{s}^{(3-5)}$.

A study conducted in a private hospital in the city of São Paulo pointed out that $16.6 \%$ of the notifications of adverse events involved falls, and, of these, $89.5 \%$ occurred in inpatient units ${ }^{(5-6)}$. Another study shows that $26.3 \%$ of falls in hospitals happened in the toilet ${ }^{(3)}$.

Patients who had histories of fall reported that the main reasons that led to the fall were loss of balance when using the toilet and muscle weakness. They also said they did not request help because they did not want to bother the nursing staff(6).

These issues are related to patient safety, which is a concern in the health area and has been discussed worldwide. Ensuring the reduction of unnecessary damage associated to health care to an acceptable minimum is a matter recognized as extremely important to achieve the quality of service ${ }^{(7)}$.

Despite the knowledge regarding the etiology and epidemiology of falls, there is a lack of prevention measures in hospitals, especially those that occur in toilets. There are methods to prevent falls in the community, but these are not well suited for hospital reality ${ }^{(6)}$.

In light of these assumptions, of the institution's concern with patient safety and seeking ways to avoid or prevent falls during the hospitalization of an elderly patient, especially when using the toilet, the nursing staff tried to develop a device that met this need.

For the difficulties found in this project, as well as in its execution, this article aims to share this experience to encourage other initiatives.

\section{OBJECTIVE}

To describe the development of a device to prevent falling for hospitalized elderly patients during the use of the toilet.

\section{METHOD}

The device was developed in a private institution of high complexity in São Paulo, which used the Mayo Clinic's SeePlan-Act-Refine-Communicate methodology (SPARC) ${ }^{(8)}$ to solve problems found in the hospital everyday life.
Considering the falling of an elderly patient in the bathroom as a serious adverse event due to the non-observance of the accompanying people in requesting aid from the nursing staff, there was a movement in the institution to seek effective ways to prevent this occurrence. From this event, several meetings were held with a group of nurses, seeking experiences, publications and products to solve the problem, but the result was unsuccessful.

In one of the meetings, there was a proposal from a "recent father", inspired in the bars in amusement park attractions and in high chairs, which seemed promising. From this suggestion began the planning of the device, then, the collaboration of clinical engineering and architecture teams in the hospital was requested to size and define the device's characteristics, so that it met the requirements of hospitalized seniors and of the assistance and institutional teams, also seeking comfort and safety on its use.

After the initial draft of the project, an institutional approval was requested, which agreed with the project and contacted a supplier of sanitary metals to produce a prototype.

The sanitary metal company projected a hinged stainless steel bar, with dimensions of $800 \times 800 \mathrm{~mm}$, which would be locked in the vertical position and, with some effort, would articulate to the position of use, providing comfort and safety to the patient. The bar was named "Safe Embrace" (Figure 1, $1^{\text {st }}$ Chart).

Safe Embrace consists of an hinged safety bar, used to assist people with disabilities when using toilets and/or shower transport chairs in general, whether it is residential or in the hospital.

This prototype, developed in two months, was installed in an apartment of Geriatrics and tested by the nursing staff. The device was tested informally by the Coordinator of the unit along with the nursing staff and patients.

The first report issued was of perfect functioning of the designed safety device, however, there was poor sizing with looseness, which allowed the patient to pass under the bar. Thus, the device was resized (Figure 1, $2^{\text {nd }}$ Chart). After, a new prototype was tested and approved by the nursing, engineering and architecture staffs, and a small adjustment was requested regarding the locking system, so that the bar could only move after unlocking, releasing its movement in the position of use, without the risk of collapsing on the patient and the care staff.

In 2012, with the changes in the type of toilets for those with a tank attached, a new adjustment was necessary, and the depth was extended to $830 \mathrm{~mm}$, which, consequently, made the bar to advance to the bathroom door, preventing its closure. The initial format was modified to adapt to this obstacle, and the edges were then chamfered (Figure 1, $3^{\text {rd }}$ Chart).

The evolution of the three Safe Embrace prototypes can be seen in Figure 1.

Figure 2 shows the final installation of the device next to the toilet.

In Figure 3, the use of Safe Embrace is simulated, showing that, even if the patient has a problem, its use prevents the chance of falling with impact to the ground.

As there was no safety device like ours on the market, a deposit of patent application regarding the product was made at the National Institute of Industrial Property ${ }^{(9)}$, registered under number MU8702739-9', with the Sociedade Beneficente Israelita Brasileira Hospital Albert Einstein as patent holder. 

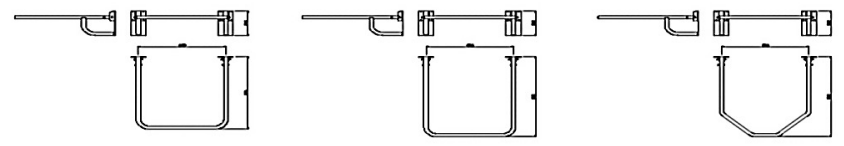

1. First version: bar with dimensions of $605 \mathrm{~mm}$ wide $x$ $750 \mathrm{~mm}$ deep

\section{Second} version: bar with dimensions of $650 \mathrm{~mm}$ wide $x$ $830 \mathrm{~mm}$ deep
3. Third version: bar with dimensions of $650 \mathrm{~mm}$ wide $x$ $830 \mathrm{~mm}$ deep, with chamfered edges of $240 \mathrm{~mm} \times 45^{\circ}$.
Figure 1 - The three versions of Safe Embrace, São Paulo, Brazil, 2012

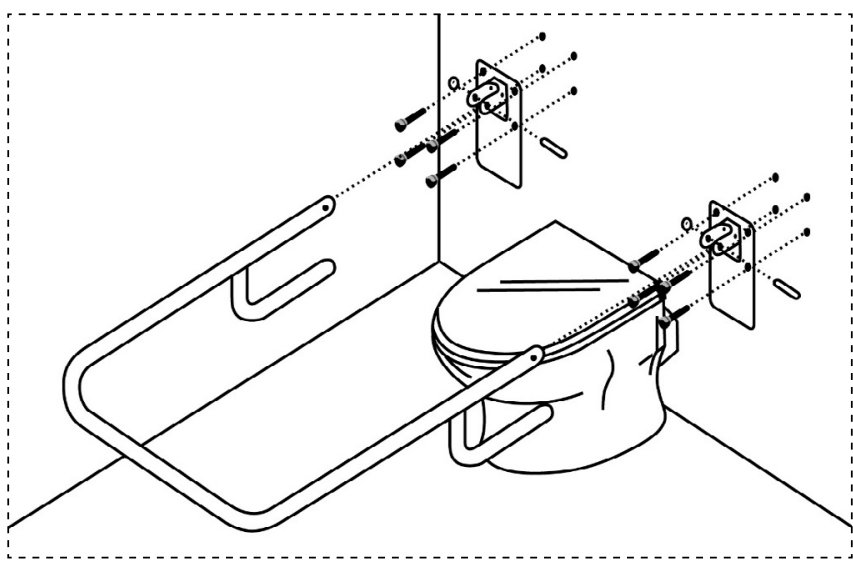

Figure 2 - Safe Embrace installed next to the toilet, São Paulo, Brazil, 2012
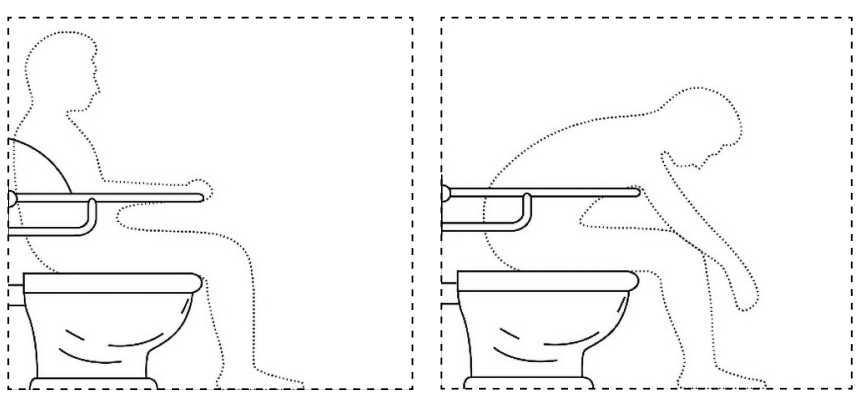

Figure 3 - Simulation of fainting with the use of the device, São Paulo, Brazil, 2012

In 2010, a contract was signed for technology transfer and patent application licensing with contractual clauses that allow royalties transfer to the creators.

We believe that Safe Embrace is a low-cost solution to prevent falling of hospitalized seniors when using the toilet. Use approval was unanimous in the assessment of the nursing staff, elderly patients, caregivers and family members. The device was adopted not only by the Geriatrics ward, but also by other specialties in the medical-surgical clinic. Other hospitals found out about it and started to use it in their wards.

\section{CONCLUSION}

To develop a device to prevent fallings from a serious adverse event was challenging for the team. Nevertheless, what seemed unfavorable brought us together and strengthened us in such a way that teamwork flowed relentlessly and spontaneously, generating the opportunity to create and contribute to the safety and privacy of hospitalized seniors.

We noticed that good solutions are not always based on large financial investments or in state-of-the-art technology. Simple ideas, built together, with the main objective centered in the patient, are effective and resolutive.

The positively assessed results were stimulating, especially by optimizing the time of patient care, since the professional can perform other tasks, such as making the bed or organizing fomites, while the patient uses the toiled protected by the Safe Embrace.

Before the creation of the device, a member of the nursing staff would stay in the bathroom along with the senior classified and identified as having high risk of falling, often inhibiting the patient's privacy. This privacy has been pointed as the main benefit of the device by the patients without cognitive limitations.

We disclosed the experience of creating Safe Embrace to promote similar initiatives. As it turned out, the device is both safe and easy to handle, and is not restricted to elderly use, as it can be extended to other groups of individuals, institutionalized of not, who seek privacy and safety, also bringing tranquility and time optimization to caregivers.

1 All the details and specifications of the Safe Embrace can be found in https://bit.ly/2n5KIvl (last access on Aug 3 2018).

\section{ERRATUM}

Article "Safe Embrace: technological innovation for elderly safety in the use of toilets", with number of DOI: http://dx.doi.org/10.1590/0034-7167-2017-0751, published in the journal Revista Brasileira de Enfermagem, 71(Suppl 6): 2833-6, in authorship:

Where to read:

\section{Luciana Mitsue Sakano Niwa', Nanci Martins Ferreira Radovich', Suely Itsuko Ciosak'}

'Universidade de São Paulo, Escola de Enfermagem. São Paulo-SP, Brasil.

Read:

\section{Luciana Mitsue Sakano Niwa', Nanci Martins Ferreira Radovich', Eliseth Ribeiro Leão", Suely Itsuko Ciosak'}

\section{'Universidade de São Paulo, Escola de Enfermagem. São Paulo-SP, Brasil. \\ "Hospital Israelita Albert Einstein, Instituto de Ensino e Pesquisa.} São Paulo-SP, Brasil.

At the header and how to cite this article, where it read: Sakano LMN, Radovich NMF, Ciosak SI

Read:

Sakano LMN, Radovich NMF, Leão ER, Ciosak SI 


\section{REFERENCES}

1. Brasil. Instituto Brasileiro de Geografia e Estatística-IBGE. Projeção da população no Brasil e nas Unidades da Federação[Internet]. 2014[cited 2014 Jun 13]. Available from: https://ww2.ibge.gov.br/apps/populacao/projecao/

2. Oliveira KGF, Becerra LA, Santos AF, Dias LC, Lopes TS, Carvalho ESS. Prevalência de fatores de risco de queda em idoso institucionalizados do município de Cachoeira. REBRASF[Internet]. 2014[cited 2016 Dec 1];1(2):44-51. Available from: http:// www.seer-adventista.com.br/ojs/index.php/RBSF/article/view/517

3. Duarte AC, Braga AIM, Carmen MM, Santesso PL, Ribeiro EL, Nascimento DNC. The implementation of a hospital's fall management protocol: results of a four-year follow-up. Rev Esc Enferm USP[Internet]. 2012[cited 2017 May 04];46(1):67-74. Available from: http://www.scielo.br/pdf/reeusp/v46n1/en_v46n1a09.pdf

4. Barros IFP, Pereira MB, Weiller TH, Anversa ETR. Internações hospitalares por quedas em idosos brasileiros e os custos correspondentes no âmbito do Sistema Único de Saúde. Rev Kairós[Internet]. 2015[cited 2016 Nov 12];18(4);63-80. Available from: https://revistas. pucsp.br/index.php/kairos/article/view/26930

5. Abreu HCA, Reiners AAO, Azevedo RCS, Silva AMC, Abreu DROM, Oliveira AD. Incidence and predicting factors of falls of older inpatients Rev Saúde Pública[Internet]. 2015[cited 2016 Jan 11];49(37):1-8. Available from: http://dx.doi.org/10.1590/ S0034-8910.2015049005549

6. Hill AM, McPhail SM, Francis-Coad J, Waldron N, Etherton-Beer C, Flicker L, et al. Educators' perspectives about how older hospital patients can engage in a falls prevention education programme: a qualitative process evaluation. BMJ Open[Internet]. 2015[cited 2016 Jan 11];5(12);e009780. Available from: https://www.ncbi.nlm.nih.gov/pmc/articles/PMC4679942/

7. World Health Organization-WHO. Direção Geral de Saúde-DGS. Estrutura Conceitual da Classificação Internacional sobre Segurança do Doente: relatório técnico final[Internet]. 2011[cited 2015 May 05];13-24. Available from: http://apps.who.int/iris/ bitstream/10665/70882/4/WHO_IER_PSP_2010.2_por.pdf

8. Salter P. A prescription for innovation[Internet]. Fast Company; 2006[cited 2014 Aug 7]. Available from: https://www.fastcompany. com/56032/prescription-innovation

9. Brasil. Instituto Nacional de Propriedade industrial-INPI. Banco de Patentes[Internet] 2012[cited 2014 May 2]. Available from: http://www.patentesonline.com.br/disposicao-construtiva-introduzida-em-barra-articulavel-de-sustentacao-e-seguranca-207382.html 